\title{
Elämästä nousee oppimisen mieli
}

\section{Silittelyjä ja selittelyjä}

En malta olla selventämättä käsityksiäni aikuisen oppimisesta ja ajatuksiani eräistä siihen liittyvistä käytännön opetustyön ongelmista, etenkin kun tarjoutui tilaisuus kirjoittaa heti Engeströmin puheenvuoron yhteyteen. Ensiksi muutama yleisluontoinen kommentti Engeströmin kirjassa ja oheisessa kirjoituksessa esittämiin ajatuksiin. Aiemmankin kirjoitukseni tarkoituksena oli kriittisistä mietteistä huolimatta myönteisen kuvan välittäminen kirjasta. Painotan vieläkin: pidän sitä oikein hyvänä kirjana, siinä tehtyä teoreettista kehittelyä mielenkiintoisena ja uusia aiheellisia vaatimuksia opetukselle asettavana. Mutta en näe näitä sinänsä hyväksi tunnustamiani opaskirjan ajatuksia yleispätevinä enkä kirjoittajan näkökulmaa ainoana hyväksyttävänä. Aikuisuus ja aikuiskasvatuksen alan moniaineksisuus asettavat paljon muunkinlaisia vaatimuksia opetukselle ja opintotilaisuuksille. Se, että painotan toista näkökulmaa ja haluan sen huomioon otettavaksi ja myös opetuskäytäntöön vaikuttavaksi, ei tarkoita, että mitätöisin Engeströmin näkökulmaa. 
Toinen tarkentamista kaipaava asia liittyy kognitiivisen psykologian ja toiminnan teorian ymmärtämiseen. Tunnustan tietoni riittämättömiksi ja viime lehdessä olleessa artikkelissani liian ylimalkaisesti mestaroin näiden teorioiden suhdetta ja Engeströmin tapaa käsitellä niitä. Se, että artikkelistani syntyi vaikutelma toiminnan teorian ymmärtämisestä ahtaana uusien tietojen sisäistämisenä johtuu, että näin se on paljolti suomeksi ilmestyneissä kirjoituksissa esitelty. Ja erityisesti oppimisen yhteydessä toiminnan teoriasta on luotu rajoittunut kuva oppimistoiminnan vaiheittaista etenemistä tarkastelevana didaktisena mallina, yhteiskunnallinen käytäntö ja toiminta on jäänyt taustalle, jos niitä on mainittu ensinkään. Tämä ei tietenkăăn riită miksikäăn puolustukseksi. Yritän perehtyä asiaan paremmin, opettaja! Toisaalta kognitiivinen näkemys on niin lavea psykologinen suuntaus, ettă tiedän hyvin pohtivani vain yhtä osa-aluetta siită. Ja se osa-alue ei ole perinteinen (?) mikrotasolla tapahtuva tiedon prosessointi vaan U. Neisserin ja J. von Wrightin esittämistä ajatuksista ja teorioista virittyvä näkemys ihmisen ja ympäröivän todellisuuden suhteesta.

\section{Elämänkokemusko arkitietoa?}

Aikuisuutta ja sen mukanaantuomaa elämänkokemusta ja -näkemystä painotan edelleen pontevasti. Se, että tämä kokemus on ristiriitaista ja myös sinänsä riittämätöntä syvällisen oppimisen tiedonlähteenä, on totta. Mutta tămă ei merkitse, etteikő oppijan arkikokemus ja sisäistetyt tiedot ja näkemykset merkittävästi - sanoisin ratkaisevasti - vaikuta mielenkiinnon heräämiseen ja suuntautumiseen ja myös oppimisessa valikoivaan mieleenpainamiseen ja muistissa säilymiseen.

Elämänkokemuksessa ei ole kysymys "vain" pintatiedosta tai arkikokemuksesta. Oppimista tapahtuu tavattoman paljon ihmisen suhteessa ympäristöön ja maailmaan, siitä millaiseen aikaan ja kulttuuriin, millaisiin yhteiskuntarattaisiin ja mille akselille sattuu syntymään, millaisissa ympäristön sanelemissa rajoissa elää ja millaisia toimintamahdollisuuksia se tarjoaa. Ja aikuisen ihmisen kokemus on vuosien, tapahtumien, oman toiminnan saatossa jäsentynyt, täsmentynyt ja monipuolistunut. Hänen elämänkokemuksensa pitää sisällään systemaattisessa koulutuksessa hankittua, oman lukemisen ja tutkimisen kautta hankittua, kantapään kautta hankittua ja monessa eri vaiheessa keskusteltua, pohdiskeltua, vertailtua ja sisäistettyä tietoa. Se ei ole "pinnal- lista arkitietoa" vaan oppijan kannalta omaa syvällistä tietoa, elämän varrella kerättyä elämysten ja arvojen värittämää kokemustietoa. Ja sivulta katsoen se ei ole irrallisen ihmisen yksilöllistä informaatiota vaan hyvin kiinteästi ympäröivăn yhteiskunnan tietotason, ajatusmaailman, sen vaatimusten ja käytäntöjen heijastusta yksilöön.

Esimerkkisi siitä, miten kokemus vahvistaa maan olevan litteä ja auringon kiertävän maata, oli varsin oivallinen. Tässä tietenkin puhutaan hieman eri tavoin kokemuksesta, sinä käytät sitä aistien välityksellä saatavana tietona ja minä elämänkokemus -merkityksessä. Mutta tuo esimerkkisi kuvastaa hyvin tietyn ajan ja alueen (tai yhteiskunnallis-historiallisen) tiedon yleistä tasoa ja ihmisten sidonnaisuutta oman yhteiskuntansa tietotasoon ja vaatimuksiin. Luultavasti Suomenniemelläkin saa tallustella varsin kauan nykypäivänä, ennenkuin löytää ihmisen, joka vain havainnointiinsa luottaen väittää maan olevan litteä jne. On keinotekoista puhua arkitiedosta silloin kun kysymys on ihmisellä tietyllä hetkellä olevasta tiedon kokonaisuudesta ja siihen välttämättömästi liittyvistä elämyksistä, arvostuksista, näkemyksistä.

Ei puhettakaan, että väittäisin kokemuksen olevan kaiken opetuksen hallitseva lähtökohta, vaan esitän, että ihmisen elämänkokemus ja -năkemys vaikuttaa aina oppimistilanteessa ja opettajan kannaltakin saattaisi olla hyödyksi ottaa se huomioon silloinkin, kun kyse on käsitteellisen tiedon opetuksesta. Opintotilaisuuteen tulevan ihmisen kannaltahan varsin usein jäsennelty, käsitteellinen tieto on etäistä, irrallista, sen oppimisessa on vaikea välttää ulkokohtaista "tietämistä'. Minua kiinnostaa olisiko nykykăytănnőssä, jossa tieteellisen tiedon logiikkaa. ympătäăn ihmisen arkielămän logiikan rinnalle, lơdettåvissă tai kehitettävissä toisin päin toimiva käytäntö, jolloin hahmotettaisiin ihmisen arkielämää ja sen logiikan ehdoista lähtien edettäisiin käsitteellisen tiedon rakenteisiin. Tai löytyisikö joitakin hyviä "välimuotoja". Vai onko tässä kyse siitä, että erilaisiin tavoitteisiin tähtäävä opetus vaatii erilaista strategiaa? Vai lieneekö sitten kyse ihmisen, oppimisen ja opetuksen ymmärtämisestä eri tavoin?

\section{Arvot mukaan oppimiseen}

En viihdy Engeströmin minulle tarjoamassa kaavussa, se ahdistaa toisaalta ja on liian väljä toisaalta eikä se tunnu lainkaan omalta. Ja luulenpa, että Engeströmin ja minun ajattelutapojen ero on toisaalla, kun mistä hän sitä etsii otaksumillaan. Engeströmin hahmotus oppimi- 
sesta reaalisen ympäristönhallinnan laajentamisena ja syventämisenä ja sisällöllisten käsitteiden omaksumisena on oppiaineksesta, sisällöstä lähtevä näkökulma. Haluamatta kieltää tippaakaan sen merkitystä ja tuomalla voimakkaasti kuitenkin mukaan oppijan -oma näkökulma, löytyy minun mielestäni ero selvemmin. Eli minä painotan oppijan aktiivisuutta ja toimintaa paitsi aineksen sisäistämisessä myös jatkuvana aktiviteettina näkemysten ja arvostusten muodostamisessa. Olipa kyse tieteellisen tiedon täydellisestä sisäistämisestä tai elämänkokemuksena saadun tiedon tietoisesta erittelystä liittyy aikuisen ihmisen oppiminen hänen omaan arkielämäänsä ja sen tavoitteisiin. Oppimisen on oltava mielekästä hänelle, on oltava jokin mieli, joka lähtee hänestä, hänen elämästään ja pyrkimyksistään eikä opetuksesta, tiedosta ja sen "ulkoapäin"' todetusta merkityksestä tai arvosta.
Pidän tärkeänä arvostusten ja näkemysten, tietoisen suhtautumisen tuomista mukaan oppi-misprosessiin - siis tahallisesti, opettajan virit-tămänă tietoisena toimintana. Joskus jossakin. aikuisen oman "oppimishistorian" vaiheessa tämä liittyy lähinnä omien kokemusten ja ha-vaintojen tai yhteisten pohdintojen ja keskuste-lujen arvottamiseen. Joskus ja jossain vaiheessa se liittyy "varsinaisessa" oppimistilanteessa opettajan esittämän tiedon, sen käyttökelpoi-suuden ja tärkeyden arvottamiseen. Ihmiselle on annettava opiskelukäytännössäkin mahdolli-suus ottaa vastuuta oppimisesta ja sen siirtämi-sestä käytäntöön. Ja tässä mielessä arvostelen Engeströmin näkemystä, se on kylläkin hyvin syvä mutta oppijan näkökulmasta suppea toi-mintamalli. Hänen omaan elämäänsä liittyvä opiskelun mieli jää huomiotta, sille ei anneta ti-laa selkiintyä vaan oppija temmataan oppiai-neksen ja opettajan ehtoihin ja arviointi ja kontrolli rajoittuvat tähän. 